\title{
РОЗВИТОК ІДЕЇ ІНДИВІДУАЛІЗАЦІЇ ПРОБЛЕМНОГО НАВЧАННЯ УЧНІВ У ВІТЧИЗНЯНІЙ ПЕДАГОГІЦІ В 50-ТІ - 70-ТІ РОКИ ХХ СТОЛІТТЯ
}

\author{
Пісоцька М. Е. \\ доктор педагогічних наук, дочент, \\ професор кафедри освітології та інноваційної педагогіки \\ Харківський національний педагогічний університет імені Г. С. Сковороди \\ вул. Алчевських, 29, Харків, Україна \\ orcid.org/0000-0002-8743-7728 \\ m.e.pisotska@gmail.com \\ Кадашевич К. О. \\ аспірантка кафедри освітологї̈ та інноваційної педагогіки \\ Харківський національний педагогічний університет імені Г. С. Сковороди \\ вул. Алчевських, 29, Харків, Украӥна \\ orcid.org/0000-0002-5762-6579 \\ k.kadashevich89@gmail.com
}

\begin{abstract}
Ключові слова: принции індивідуалізації навчання, принции проблемності навчання, нормативноправова база, індивідуальнотипологічні особливості учнів, рівень вирімення проблемних ситуацій, методи проблемного навчання, етапи розумового процесу, критерії реалізаціï.
\end{abstract}

У статті схарактеризовано підходи до тлумачення ключових понять дослідження, надано власні їх визначення, згідно з якими індивідуалізація навчання трактується як процес, спрямований на розвиток індивідуальності, формування індивідуальної стратегії самовизначення та самореалізації, що передбачає найповніше урахування індивідуальних особливостей кожного його учасника, реалізацію системи індивідуалізованих способів і прийомів, взаємозумовлених дій вчителя та учнів на всіх етапах навчальної діяльності; проблемне навчання - як вид навчання, що передбачає створення вчителем на уроці проблемних ситуацій та організацію їх вирішення на рівні навчальних можливостей учнів.

На основі аналізу психолого-педагогічної літератури розкрито сутність принципу проблемності, мету проблемного навчання, психологічну структуру проблемної ситуації, розумові дії учнів щодо іiі вирішення.

Наведено фактори, які сприяли актуалізації ідеї індивідуалізації проблемного навчання у 50-ті роки; напрями досліджень вітчизняних педагогів та психологів, що слугували у ці часи науковим підгрунтям для розвитку в подальшому індивідуалізації проблемного навчання; нормативні документи, положення яких були підставою для активної розробки теорії індивідуалізації проблемного навчання вітчизняними науковцями у 60 -ті - 70-ті роки.

Підкреслено визнання науковцями однією з основних вимог до організації проблемного навчання його здійснення на межі трудності, тобто в зоні найближчого розвитку учнів; визначення у якості показника трудності ступеня узагальнення, якого повинен досягти учень у процесі виявлення нового знання в проблемній ситуації; обгрунтування важливості поступового зростання рівня складності проблеми для розвитку учнів; виділення певних індивідуально-типологічних особливостей школярів як умов ефективності проблемного навчання, умовних рівнів вирішення проблемних ситуацій, підстав для переводу школярів 3 досягнутого рівня на вищий.

Наголошено на зведенні науковцями різних рівнів проблемності у ранг об'єктивної основи для виділення різних методів навчання; доведенні ефективності здійснення індивідуалізації на всіх етапах проблемного навчання, застосування конкретних способів диференціації проблемного навчання учнів на уроці, обрання певних критеріїв реалізації проблемного навчання з огляду на індивідуальні особливості учнів. 


\title{
DEVELOPMENT OF THE INDIVIDUALIZATION IDEA OF STUDENT PROBLEM-BASED LEARNING IN DOMESTIC PEDAGOGY OF THE 5OS - 70S OF THE XX CENTURY
}

\author{
Pisotska M. E. \\ Doctor of Pedagogical Sciences, Associate Professor, \\ Professor at the Department of Education and Innovative Pedagogy \\ H. S. Skovoroda Kharkiv National Pedagogical University \\ Alchevskykh str., 29, Kharkiv, Ukraine \\ orcid.org/0000-0002-8743-7728 \\ m.e.pisotska@gmail.com \\ Kadashevych K. O. \\ Postgraduate Student at the Department of Education and Innovative Pedagogy \\ H. S. Skovoroda Kharkiv National Pedagogical University \\ Alchevskykh str., 29, Kharkiv, Ukraine \\ orcid.org/0000-0002-5762-6579 \\ k.kadashevich89@gmail.com
}

Key words: individualization principle in learning, problemacity principle in learning, regulatory and legal framework, individual and typological features of students, level of solving problem situations, methods of problembased learning, stages of the mental process, implementation criteria.
The article describes the approaches to defining key research concepts, provides their own definitions.

Based on the analysis of psychological and pedagogical literature, the essence of the problemacity principle, the purpose of problem-based learning, the psychological structure of the problem situation, the mental actions of students to solve it are revealed.

The factors that contributed to the actualization of the individualization idea of problem-based learning in the 50s; lines of research of domestic pedagogues and psychologists, which served at that time as a scientific basis for its further development; regulatory documents, the provisions of which were the basis for the active development of the individualization theory of problem-based learning by domestic scientists in the $60 \mathrm{~s}-70 \mathrm{~s}$ are given.

Emphasis is placed on the recognition by scientists of one of the main requirements to the organization of problem-based learning - it is its implementation on the verge of difficulty, i.e. in the area of immediate development of students; determining by them as an indicator of difficulty the degree of generalization that the student must achieve in the process of identifying new knowledge in a problem situation; substantiation of the importance of gradually increasing the level of complexity of the problem for the development of students; selection of certain individual and typological features as conditions of efficiency of problem-based learning, conditional levels of solving problem situations, grounds for transferring the student from the achieved level to a higher one. Emphasis is placed on the raising of different levels of problemacity by scientists to the rank of an objective basis for the selection of various learning methods; proving by them the efficiency of individualization at all stages of problem-based learning, the use of specific methods of problem-based learning differentiation of students at the lesson, the choice of certain criteria in the implementation of problem-based learning given the individual characteristics of students. 
Постановка проблеми. Стратегічним курсом удосконалення загальної середньої освіти України визначено $\dddot{11}$ гуманізацію, тобто орієнтацією на найповніше задоволення різноманітних освітніх потреб учнів, набуття ними компетентностей з урахуванням особистих навчальних цілей, уподобань, здійснення допомоги в життевому самовизначенні та самореалізації на основі встановлення партнерських взаємовідносин між суб' єктами освітнього процесу (Державна національна програма «Освіта» («Україна XXI століття»), Національна доктрина розвитку освіти України у XXI столітті, Національна стратегія розвитку освіти в Україні на період до 2021 року, Концепція реалізації державної політики у сфері реформування загальної середньої освіти «Нова українська школа» на період до 2029 року).

Вирішенню поставленого завдання сприяе пошук шляхів реалізації можливостей індивідуалізації навчального процесу.

У сучасних науково-педагогічних дослідженнях індивідуалізація навчання вивчається як засіб: забезпечення позитивної мотивації до навчання (О. Гребенюк, Т. Гребенюк, Т. Головань, Б. Дьяченко, О. Фаст та інші); формування пізнавальної активності та самостійності як якостей особистості (Я. Бойко, В. Буряк, Н. Лобко-Лобановська, В. Лозова, О. Малихін та інші); розвитку творчих здібностей (В. Кушнір, Г. Кушнір, Н. Рожкова, О. Скориніна, Н. Федорова та інші); організації навчання у різних формах (Г. Васьківська, Т. Дейниченко, Л. Липова, Н. Пожар, Г. Саранцев та інші); упровадження комп'ютерного (Т. Гергей, В. Ляудіс, Є. Машбиць, О. Тихомиров та інші), дистанційного (Н. Жевакіна, Т. Іванова, О. Собаєва, П. Стефаненко, О. Хмель та інші), адаптивного (В. Богорєв, А. Іванов, Ю. Машбиць, О. Огієнко, П. Федорчук), кредитно-модульного (Т. Алексєєнко, T. Козак, I. Мороз, А. Фурман, П. Юцявічене та інші) навчання. Предметом наукового пошуку науковців (Г. Адамова, Л. Борисенко. Н Журавська, Л. Конопляник, О. Повідайчик та інші) є й різні аспекти організації проблемного навчання. Однак сьогодні відсутнє дослідження, у якому комплексно та системно аналізується теорія і практика індивідуалізації проблемного навчання учнів у вітчизняних закладах загальної середньої освіти другої половини XX століття.

Мета статті - аналіз та уточнення відомих раніше, але недостатньо вивчених фактів, висновків, рекомендацій, що містяться у вітчизняних нормативних документах діяльності закладів загальної середньої освіти та психолого-педагогічній літературі з питань індивідуалізації проблемного навчання.

Виклад основного матеріалу дослідження. Зауважимо, що в науково-педагогічних працях відсутній єдиний підхід до визначення категорій «індивідуалізація навчання» та «проблемне навчання», існуєтенденція допоступовогозмістовного уточнення й наповнення цих термінів. Серед наявних визначень виділимо підходи, згідно з якими:

- індивідуалізація навчання визначається як дидактичний принцип (О. Братанич, Ю. Олексін, Д. Чернілевський), педагогічний процес (I. Бєлогорцева, Т. Васильєва, О. Невмержицький, В. Сластьонін), система (Д. Байсалов, Т. Годованюк, А. Кірсанов, М. Солдатенко), відокремлення (виділення) учня в процесі навчання (Н. Лобко-Лобановська), урахування індивідуальних особливостей тих, хто навчається (В. Гольховой, В. Крутецький, С. Мелікова, Н. Прасол, I. Унт), процес розкриття індивідуальності (В. Володько, О. Іванова), трансформації особистості (С. Масич, А. Нісемчук, О. Панасюк);

- проблемне навчання трактується як сукупність певних специфічних дій вчителя та учнів (В. Оконь), система методів (П. Лузан, Д. Чернилевский), процес взаємодії викладача і студента на суб'єкт-суб'єктному рівні (О. Повідайчик), принцип навчання (М. Махмутов, Г. Понурова), тип розвивального навчання (I. Лернер, М. Фіцула), технологія навчання (Г. Адамова, Н. Журавська, С. Яблоков).

У нашому дослідженні категорію «індивідуалізація навчання» визначаємо як процес, спрямований на розвиток індивідуальності, формування індивідуальної стратегії самовизначення та самореалізації, що передбачає найповніше урахування індивідуальних особливостей кожного його учасника, реалізацію системи індивідуалізованих способів і прийомів, взаємозумовлених дій вчителя та учнів на всіх етапах навчальної діяльності.

Поняття «проблемне навчання» трактуємо як вид навчання, що передбачає створення вчителем на уроці проблемних ситуацій та організацію їх вирішення на рівні навчальних можливостей учнів.

Актуалізацію розробки ідеї індивідуалізації проблемного навчання у 50-ті роки після його заборони в УРСР на початку 30 -х років пов'язуємо, $з$ одного боку, з необхідністю післявоєнного відродження країни, подолання нестачі кваліфікованих кадрів, а з іншого боку, з наявністю в багатьох школах другорічництва й низької успішності учнів (наказ № 56 від 11.02.1950 р. «Про підсумки січневих нарад учителів й завдання відділів народної освіти та шкіл», наказ № 587 від 27.08.1952 р. «Про підсумки роботи шкіл робітничої та сільської молоді за 1951/52 навчальний рік й завдання на 1952/53 навчальний рік»). Серед причин останнього факту в передових статтях педагогічної преси цих років називалися серйозні недоліки «у самому навчальному процесі, у системі та методах навчання» $[18$, с. 6]; зосередження 
уваги вчителів «на тому, чому навчати» та ігнорування «майже повністю того, як навчаються діти» $[18$, с. 9]; недооцінка вчителями ролі самостійної роботи учнів $[18$, с. 8] та не завжди уміле поєднання на уроці колективної форми роботи з індивідуальним підходом до окремих учнів [18, с. 10].

Тому в нормативних документах, що спрямовували діяльність закладів загальної середньої освіти у 50-ті роки, наголошувалося на необхідності застосування вчителями на уроках активних методів роботи з учнями, які б сприяли свідомому сприйняттю ними навчального матеріалу, розвитку їх самостійного мислення (наказ № 101 від 12.08.1958 р. «Про підсумки роботи шкіл Української РСР за 1957/58 навчальний рік й завдання шкіл, відділів народної освіти та інститутів удосконалення кваліфікації вчителів у 1958/59 навчальному році»).

Підкреслимо, що науковим підгрунтям для організації проблемного навчання 3 урахуванням індивідуальних особливостей учнів було формулювання основної суперечності процесу навчання (М. Данилов, 1959 р.) як протиріччя «між навчальними та практичними завданнями, що висуваються у ході навчання, та наявним рівнем знань, умінь, розумового розвитку тих, хто навчається» $[9$, с. 42]; виявлення недоліків у розумових операціях учнів, подолання яких дозволить підняти їхню аналітико-синтетичну діяльність до рівня володіння загальним методом мислення для успішного вирішення будь-яких задач [13]; виділення індивідуальних відмінностей перенесення прийомів розумової діяльності в нові умови [11] та індивідуальних особливостей учнів, від яких залежить якість аналітично-синтетичної діяльності (рівень узагальнених умінь у певній галузі діяльності, рівень попереднього досвіду в рішенні задач конкретного типу, рівень научуваності з їі проявами (швидкістю засвоєння, темпом просування) та пов' язаний з нею рівень оволодіння аналітико-синтетичними операціями, рівень співвідношення почуттєвих та абстрактних компонентів розумової діяльності, рівень гнучкості мислення) [5].

У ході дослідження встановлено, що активний розвиток теорії індивідуалізації проблемного навчання припав на 60-ті - 70-ті роки у зв' язку з наявними у нормативних документах діяльності закладів загальної середньої освіти вимогами щодо удосконалення навчального процесу, урізноманітнення форм і методів навчання (директиви XXIV (1971 р.) та XXV (1976 р.) з'їдів партії, Постанова Верховної Ради СРСР від 19.07.1973 р. «Про стан народної освіти і заходи щодо подальшого вдосконалення загальної середньої, професійно-технічної, середньо-спеціальної та вищої освіти в СРСР); співмірного розвитку форм творчого оволодіння знаннями (наказ № 249 від 20.09.1972 р.
«Про заходи по виконанню постанов ЦК КПРС і Ради Міністрів СРСР» від 18.07.1972 р. № 535 та наказ ЦК КП України і Ради Міністрів УРСР від 08.08.1972 p. № 370 «Про дальше вдосконалення вищої освіти»); більшого використання проблемного навчання (наказ Міністерства освіти УРСР № 33 від 20.02.1970 р. «Про поліпшення якості знань учнів з основ наук у школах УРСР»); значного покращення вивчення індивідуальних особливостей учнів та ширшого використання наслідків цього вивчення в навчальному процесі (Рішення колегії від 19.04. 1971 р. «Про вивчення індивідуальних особливостей учнів»).

Розробку теорії проблемного навчання пов'язуємо 3 обгрунтуванням науковцями принципу проблемності, який відображає «закономірності зміни структури змісту навчального матеріалу $\mathrm{i}$ поєднання методів навчання на основі логіко-пізнавальних протиріч» $[17$, с. 33]. Оскільки проблемне навчання передбачає організацію самостійного відкриття учнями висновків науки, способів дій, винаходу нових способів використання знань на практиці, його метою визнавали засвоєння не тільки системи знань як результату наукового пізнання, але й самого шляху, процесу отримання цього результату [16, с. 20].

Реалізацію принципу проблемності пов'язували зі створенням проблемної ситуації як інтелектуального утруднення, що виникає у разі незнання учнем того, як пояснити певне явище, факт, процес дійсності, неможливості досягнути мети відомим йому способом дії [16, с. 30]; ncuхічного стану учня як суб'єкта учіння при виконанні ним завдання, яке вимагає знайти (відкрити чи засвоїти) нові, раніше не відомі йому знання чи способи дії [15].

Компонентами психологічної структури проблемної ситуації, окрім невідомих знань чи способів дії, що відкриваються учнем, визначали пізнавальну потребу, індивідуальний інтерес, які спонукають його до інтелектуальної діяльності, слугують умовою прийняття ним проблеми до наступного вирішення та спираються на його інтелектуальні можливості, які включають творчі здібності і минулий досвід [15].

Згідно $з$ виділеними С. Рубінштейном етапами розумового процесу, етапами вирішення проблемної ситуації вважали такі: усвідомлення учнями суперечностей, інтелектуального утруднення у зв'язку з виникненням проблемної ситуації; осмислення ними проблеми та їі прийняття; пошук учнями найраціональнішого іiі розв'язання, що вимагає розчленування навчальної задачі на ряд окремих, висунення гіпотез, їх аналіз і визначення операцій, правил, необхідних для розв'язання й перевірки правильності вирішення раніше засвоєних знань; формулювання кінцевого 
судження, у якому зафіксовано остаточний результат розв'язаної проблеми, та його практична перевірка $[10$, с. 16].

Аналіз праць науковців (Л. Арістова (1968 p. [1]), В. Барабаш (1974 p. [4], 1975 p. [3], 1978 p.) [2], С. Векслер (1978 р. [6]), Д. Вількєєв (1974 р.) [7], А. Габібулін (1974 р. [7]), Ю. Гільбух (1974 p. [8]), В. Гетта (1980 р. [20]), В. Свдокімов (1978 p. [2]), В. Крутецький (1972 р. [12]), О. Матюшкін (1972 p. [15]), М. Махмутов (1977 p. [16]), М. Ричік, 1974 р. [8], Д. Тхоржевський (1980 p. [20] та інші), які розробляли питання проблемного навчання у 60-ті - 70-ті роки, переконує в обгрунтуванні ними важливості його індивідуалізації. Так, однією з основних вимог до організації проблемного навчання визнавали його здійснення на межі трудності, тобто в зоні найближчого розвитку учнів, де проблемна ситуація має якісно складніше вираження [3, с. $25 ; 12$, с. 50.]. У якості показника трудності визначали не просто ступінь новизни засвоюваних знань, а той ступінь узагальнення, якого повинен досягти учень у процесі виявлення нового знання в проблемній ситуації [15]. Наявністю навчальних проблем різного рівня складності, відмінністю їхнього сприйняття й формулювання кожним учнем, рішенням при специфічних для кожного учня умовах, висуненням різноманітних гіпотез, знаходженням інших шляхів та засобів їхнього доведення обгрунтовували важливість поступового зростання рівня складності проблеми для розвитку учнів $[1$, с. 112 ; 3 , c. $12 ; 12$, c. $50 ; 16$, c. $23 ; 20$, c. 61$]$.

Доводячи детермінованість процесу вирішення проблемних ситуацій індивідуально-типологічними особливостями школярів, науковці вважали певний рівень їхнього розвитку умовою ефективного застосування проблемного навчання. До його особливостей відносили такі: навченість - систематизованість знань та уміння оперувати ними (В. Барабаш, 1975 р. [3, с. 12], О. Матюшкін, 1972 р. [15], Ю. Самарін, 1964 р. $[19$, с. 51$])$; научуваність - здібність до навчання, тобто оволодіння необхідними логічними операціями, гнучкість мислення тощо); достатню мотивацію, самооцінку власних можливостей [3, с. 7]; пошукові навички - уміння співвідносити умову і питання завдання, дані в умові завдання між собою і з вимогами завдання, повноту та достовірність доказів тощо) (В. Барабаш, 1975 р. [3, с. 12]); обсяг оперативної пам'яті, стійкість і сконцентрованість уваги учнів (Ю. Гільбух, М. Ричік, 1974 р. $[8$, с. 35$])$; силу і рухливість нервової системи, динамічність, характер розумової діяльності (С. Векслер, 1978 р. [6, с. 20], Ю. Самарін, 1964 р. $[19$, с. 51]); пізнавальну активність, пізнавальну самостійність (В. Барабаш, 1975 р. [3, с. 12], С. Векслер, 1978 р. [6, с. 20], В. Гетта, Д. Тхор- жевський, 1980 р. [20, с. 61]); суб’єктивний досвід учнів, уміння використовувати власний досвід при висуненні гіпотез (Д. Вількєєв, 1964 р. [7]).

Науковці (В. Барабаш (1978 р. [2]), Д. Вількєєв (1974 p. [7]), А. Габібулін (1974 р. [7]), В. Гетта (1980 p. [20]), В. Євдокімов (1978 р. [2]), В. Крутецький (1972 р. [12]), М. Махмутов (1977 р. [16]) та інші) обумовлювали природою проблемної ситуації, індивідуально-типологічними відмінностями учнів та ступенем їхньої навченості методам проблемного учіння визначення умовних рівнів вирішення проблемних ситуацій.

Зокрема, Д. Вількєєв, А. Габібулін виділяли три умовні рівні пошукової самостійності при рішенні проблеми: рішення за допомогою вчителя в процесі евристичної бесіди; рішення проблеми методом самостійної роботи на основі розчленування проблеми на ряд окремих питань, які відіграють роль евристичної програми; самостійне рішення проблеми [7, с. 9].

М. Махмутов до цих умовних рівнів відносив такі: рівень несамостійної (звичайної) активності, що передбачає сприйняття учнем пояснення вчителя, засвоєння зразка розумових дій в умовах проблемної ситуації, усне відтворення, виконання учнем самостійних робіт відтворювального характеру; рівень напівсамостійної активності, який характеризується участю учнів у пошуку способів рішення поставленої вчителем навчальної проблеми та застосуванням попередніх знань в іншій ситуації; рівень самостійної активності, що проявляється через виконання робіт репродуктивно-пошукового типу, коли учень сам працює за текстом підручника, використовує попередні знання в новій ситуації, конструює, вирішує задачі середнього рівня складності, доводить гіпотези 3 незначною допомогою вчителя; рівень творчої активності, який передбачає виконання самостійних робіт на прояв творчої уяви, логічного аналізу та здогадки, здійснення відкриття нового способу рішення навчальної проблеми, самостійного доказу, власних висновків та узагальнень, винаходів та написання художніх творів.

Підставою для переводу школярів 3 досягнутого рівня на більш високий автор вважав сформованість відповідно до етапів вирішення проблем певних умінь. Це такі уміння: бачити та усвідомлювати, формулювати або переформулювати проблему; висувати припущення та гіпотези; здійснювати їхнє обгрунтовування та доказ; використовувати на практиці знайдений спосіб вирішення проблеми [16, с. 41-42].

Підкреслимо, що різні рівні проблемності М. Махмутов зводив у ранг об'єктивної основи побудови варіантів поєднання прийомів викладання і прийомів учіння, тобто різних методів навчання [17, с. 32-33]. 
У якості таких методів В. Крутецьким залежно від того, які ланки процесу навчання передаються вчителем учням, названо такі методи проблемного навчання: учитель ставить проблему, формулює їі та спрямовує школярів на самостійне знаходження шляхів вирішення цієї проблеми; учитель ставить проблему, але формулюють та вирішують ii учні самостійно; школярі самі бачать проблему, самостійно іiі формулюють, досліджують можливості та способи їі вирішення при вмілому керівництві та контролю з боку вчителя [12, с. 49].

Крім того, науковцями доведена ефективність: для активізації пізнавальних сил учнів диференціації змісту їхньої пошукової діяльності при рішенні ними єдиної для всіх проблеми (Л. Арістова, 1968 р. [1]); диференціації самостійної пошукової діяльності для формування здібності до теоретичного передбачення та пояснення спостережуваних явищ, інтуїтивного рішення проблеми (Д. Вількєєв, А. Габібулін, 1974 р. [7]); індивідуалізації та диференціації на всіх етапах проблемного навчання; певної організації диференційованого проблемного уроку, коли вчитель від загальної класної фронтальної роботи переходить до групової та індивідуальної, а потім на конкретному етапі знову повертається до колективної (В. Барабаш, 1975 р. [3]); спеціальної методики, що передбачає надання учням, які не можуть самостійно творчо мислити, після невдалих спроб зробити певні дії з вирішення проблемної ситуації зразка виконання подібних проблемних завдань (С. Векслер, 1978 р. [6]); створення тимчасових диференційованих груп на кожному проблемному занятті для вирішення певних зорієнтованих на конкретну групу навчальних завдань (Н. Буряк, В. Марков, 1981 р. [14, с. 19]).

3 огляду на досліджувану нами проблему заслуговують на увагу виділені М. Махмутовим критерії реалізації проблемного навчання, що вимагають якісної оцінки (рівень ціннісної орієнтації учнів, сформованості загальнонавчальних, навчально-пізнавальних умінь учнів у структурі певного рівня проблемності, при- йоми викладання) та кількісної оцінки (кількість зроблених учнем пізнавальних дій стосовно формулювання проблемного питання (виділення проблеми), висунення припущення про спосіб вирішення тощо) [17, с. 36].

Висновки. Таким чином, поштовхом до активного розвитку теорії індивідуалізації проблемного навчання у 60-ті - 70-ті роки слугувало висунення у нормативно-правових документах, що спрямовували діяльність закладів загальної середньої освіти, вимоги удосконалити навчальний процес через його збагачення формами творчого оволодіння знаннями та більш широке використання наслідків вивчення індивідуальних особливостей учнів. У ці часи вітчизняними науковцями обгрунтовано важливість реалізації та сутність принципу проблемності, сформульовано мету проблемного навчання, надано визначення проблемної ситуації, компонентом іiі психологічної структури виділено пізнавальну потребу школярів як умову прийняття ними проблеми до наступного вирішення та їхні інтелектуальні можливості. Однією 3 основних вимог до організації проблемного навчання визнано його здійснення на межі трудності, тобто в зоні найближчого розвитку учнів. Доведено доцільність поступового зростання рівня складності проблеми. Виявлено такі індивідуальні особливості учнів, від рівня розвитку яких залежить ефективність застосування проблемного навчання: навченість, научуваність, пошукові навички, обсяг оперативної пам'яті, стійкість і сконцентрованість уваги, сила і рухливість нервової системи, динамічність, характер розумової діяльності, пізнавальна активність та самостійність, суб'єктивний досвід, уміння використовувати його при висуненні гіпотез. 3 огляду на індивідуальні особливості учнів обгрунтовано різні рівні вирішення проблем; основи для переводу тих, хто навчається, 3 досягнутого рівня на більш високий; способи індивідуалізації проблемного навчання; критерії оцінки його результатів. У подальшому планується продовження аналізу розвитку досліджуваної проблеми в інші роки ХХ століття.

\section{ЛIТЕРАТУРА}

1. Аристова Л. Активность учения школьников. Москва : Просвещение, 1968. 137 с.

2. Барабаш В.П., Євдокімов В.І. Індивідуальний підхід до учнів в умовах проблемного навчання. Питання проблемного навчання. Київ : Радянська школа, 1978. С. 108-121.

3. Барабаш В.П. Индивидуальный поход к учащимся в условиях проблемно-поисковой деятельности : автореф. дис. ... канд. пед. наук : 13.00.01. Одесса, 1975. 26 с.

4. Барабаш В.П. Особливості індивідуального підходу до учнів в умовах проблемного навчання. Радянська школа. 1974. № 5. С. 29-33.

5. Богоявленский Д.Н., Менчинская Н. А. Психология усвоения знаний в школе. Москва : АПН РСФСР, 1959. 346 с.

6. Векслер С.І. Умови підвищення ефективності проблемного навчання. Радянська школа. 1978 . № 11. C. 18-22. 
7. Габибулин А.С., Вилькеев Д.В. Методика организации поисковой познавательной деятельности учащихся на проблемних уроках физики в VI классах. Казань, 1974. 45 с.

8. Гільбух Ю.З., Ричік М.В. Актуальні психологічні питання застосування проблемного навчання. Радянська школа. 1974. № 8. С. 32-37.

9. Данилов М.А. Процесс обучения в советской школе. Москва : Учпедгиз, 1960. 299 с.

10. Делікатний К.Г., Ржецький М.М. Про сутність проблемного навчання. Радянська школа. 1983. № 2. С. $12-17$.

11. Кабанова-Меллер Е.Н. Формирование приемов умственной деятельности у школьников. Советская педагогика. 1959. № 6. С. 78-86.

12. Крутецький В.А. Формування і розвиток здібностей учнів. Радянська школа. 1972. № 4. С. 44-51.

13. Ланда Л.Н. О формировании мыслительной деятельности при решении задач. Bonpocbl nсихологии. 1959. № 3. C. 14-27.

14. Марков В.В., Буряк Н.І. Про необхідність диференційованого підходу до учнів у проблемному навчанні. Радянська школа. 1981. № 12. С. 17-22.

15. Матюшкин А.М. Проблемные ситуации в мышлении и обучении. Москва: Педагогика, 1972. 208 с.

16. Махмутов М.И. Организация проблемного обучения в школе. Книга для учителей. Москва.: Просвещение, 1977. 240 с.

17. Махмутов М.И. Принцип проблемности в обучении. Вопросы психологии. 1984. № 5. С. 30-36.

18. Повысить уровень учебной работы в школе. Советская педагогика. 1956. № 5. С. 3-11.

19. Самарин Ю. Развитие и воспитание ума. Народное образование. 1964. № 8. С. 50-51.

20. Тхоржевський Д.О., Гетта В.Г. Проблемне навчання на уроках праці. Київ : Радянська шола, 1980. 150 c.

\section{REFERENCES}

1. Aristova L. (1968) Aktivnost ucheniya shkolnikov [Teaching Activity of Schoolchildren]. Moscow: Education. 137 p.

2. Barabash V.P., Yevdokimov V.I. (1978) Indyvidualnyi pidkhid do uchniv v umovakh problemnoho navchannya. Pytannya problemnoho navchannya [Individual Approach to Students in the Context of Problem-Based Learning. Issues of Problem-Based Learning]. Kyiv: Soviet School. PP. 108-121.

3. Barabash V. P. (1975) Individualnyy pokhod k uchashchimsya v usloviyakh problemno-poiskovoy deyatelnosti [Individual Approach to Students in the Terms of Problem and Search Activity]: synopsis of a thesis ... cand. sc. education: 13.00.01. Odessa. $26 \mathrm{p}$.

4. Barabash V.P. (1974) Osoblyvosti indyvidualnoho pidkhodu do uchniv v umovakh problemnoho navchannya [Features of Individual Approach to Students in Terms of Problem-Based Learning]. Soviet School. No. 5. PP. 29-33.

5. Bogoyavlenskiy D.N., Menchinskaya N.A. (1959) Psikhologiya usvoyeniya znaniy v shkole [Psychology of Acquisition of Knowledge at School]. Moscow: APS RSFSR. 346 p.

6. Veksler S.I. (1978) Umovy pidvyshchennya efektyvnosti problemnoho navchannya [Conditions for Improving the Efficiency of Problem-Based Learning]. Soviet School. No. 11. PP. 18-22.

7. Gabibulin A.S., Vilkeev D.V. (1974) Metodika organizatsii poiskovoy poznavatelnoy deyatelnosti uchashchikhsya na problemnikh urokakh fiziki v VI klassakh [Methodology of Organizing the Search Cognitive Activity of Students at the Problem Physics Lessons for VI Grades]. Kazan. 45 p.

8. Hilbukh Yu.Z., Rychik M.V. (1974) Aktualni psykholohichni pytannya zastosuvannya problemnoho navchannya [Actual Psychological Issues of Application of Problem-Based Learning]. Soviet School. No. 8. PP. 32-37.

9. Danilov M.A. (1960) Protsess obucheniya v sovetskoy shkole [Teaching Process in the Soviet School]. Moscow: Educational and Pedagogical Publishing House. 299 p.

10. Delikatnyi K.H., Rzhetskyi M.M. (1983) Pro sutnist problemnoho navchannya [On the Essence of Problem-Based Learning]. Soviet School. No. 2. PP. 12-17.

11. Kabanova-Meller E.N. (1959) Formirovaniye priyemov umstvennoy deyatelnosti u shkolnikov [Formation of Methods of Mental Activity of Schoolchildren]. Soviet Pedagogy. No. 6. PP. 78-86.

12. Krutetskyi V.A. (1959) Formuvannya i rozvytok zdibnostey uchniv [Formation and Development of Students' Abilities]. Soviet School. No. 4. PP. 44-51.

13. Landa L.N. (1959) O formirovanii myslitelnoy deyatelnosti pri reshenii zadach [On the Formation of Mental Activity When Solving Problems]. Psychological Issues. No. 3. PP. 14-27.

14. Markov V.V., Buryak N.I. (1981) Pro neobkhidnist dyferentsiyovanoho pidkhodu do uchniv u problemnomu navchanni [On the Need for a Differentiated Approach to Students in Problem-Based Learning]. Soviet School. No. 12. PP. 17-22. 
15. Matyushkin A.M. (1972) Problemnyye situatsii v myshlenii i obuchenii [Problem Situations in Thinking and Learning]. Moscow: Pedagogy. 208 p.

16. Makhmutov M.I. (1977) Organizatsiya problemnogo obucheniya v shkole. Kniga dlya uchiteley [Organization of Problem Learning at School. Book for Teachers]. Moscow: Education. 240 p.

17. Makhmutov M.I. (1984) Printsip problemnosti v obuchenii [Problemacity Principle in Learning]. Psychological Issues. No. 5. PP. 30-36.

18. (1956) Povysit uroven uchebnoy raboty v shkole [To Improve the Level of Educational Work at School]. Soviet Pedagogy. No. 5. PP. 3-11.

19. Samarin Yu. (1964) Razvitiye i vospitaniye uma [Development and Education of the Mind]. Public Education. No. 8. PP. 50-51.

20. Thorzhevskyi D.O., Hetta V.H. (1980) Problemne navchannya na urokakh pratsi [Problem-Based Learning at the Labor Lessons]. Kyiv: Soviet School. 150 p. 